\title{
Low-density lipoprotein promotes lymphatic metastasis of esophageal squamous cell carcinoma and is an adverse prognostic factor
}

\author{
HONGBIN DENG ${ }^{1,2^{*}}$, TAO ZHOU ${ }^{1 *}$, XINKAI MO ${ }^{3}$, CHENGXIN LIU $^{1}$ and YONG YIN ${ }^{1}$ \\ ${ }^{1}$ Department of Radiation Oncology, Shandong Cancer Hospital Affiliated to Shandong University, \\ Shandong Academy of Medical Sciences, Jinan, Shandong 250117; ${ }^{2}$ School of Medicine and Life Science, \\ University of Jinan-Shandong Academy of Medical Science, Jinan, Shandong 25022; ${ }^{3}$ Department of Laboratory, \\ Shandong Cancer Hospital Affiliated to Shandong University, Shandong Academy of Medical Sciences, \\ Jinan, Shandong 250117, P.R. China
}

Received February 22, 2018; Accepted September 19, 2018

DOI: $10.3892 / \mathrm{ol} .2018 .9683$

\begin{abstract}
The purpose of the current study was to investigate the prognostic role of preoperative serum lipid levels in patients with esophageal squamous cell carcinoma (ESCC) and to preliminarily explore the mechanism of serum lipids in this disease. Preoperative lipids, including total cholesterol, low-density lipoprotein (LDL) cholesterol, high-density lipoprotein (HDL) cholesterol and triglyceride levels, were assessed in 242 patients with ESCC. To eliminate the influence of nutritional status, all patients had previously undergone esophagectomy. Univariate and multivariate Cox regression analyses were performed to identify predictors of overall survival (OS). Associations between significant lipid targets and clinical features were then analyzed and the results were validated using TE-1 and ECa109 esophageal cancer cell lines. The cell proliferation was evaluated with a Cell Counting Kit-8 (CCK8) assay and the cell cycle was assessed with propidium iodide staining and flow cytometry. Univariate analysis revealed that HDL $(\mathrm{P}=0.048)$, LDL ( $\mathrm{P}=0.020)$, Pathological T-staging status (pT status) $(\mathrm{P}=0.001)$, Pathological $\mathrm{N}$-staging status ( $\mathrm{pN}$ status) $(\mathrm{P}=0.001)$ and histological differentiation $(\mathrm{P}=0.002)$ were significantly associated with OS. Based on multivariate
\end{abstract}

Correspondence to: Professor Yong Yin or Dr Chengxin Liu, Department of Radiation Oncology, Shandong Cancer Hospital Affiliated to Shandong University, Shandong Academy of Medical Sciences, 440 Jiyan Road, Jinan, Shandong 250117, P.R. China

E-mail: yinyongsd@126.com

E-mail: liu.chengxin.2008@163.com

*Contributed equally

Key words: low-density lipoprotein, esophageal squamous cell carcinoma, prognosis, lymphatic metastasis, in vitro experiment analysis, LDL [hazard ratio $(\mathrm{HR})=2.164, \mathrm{P}=0.005]$, $\mathrm{pT}$ status $(\mathrm{HR}=1.714, \mathrm{P}=0.001)$, $\mathrm{pN}$ status $(\mathrm{HR}=1.966, \mathrm{P}=0.001)$ and histological differentiation $(\mathrm{HR}=4.083, \mathrm{P}=0.002)$ were risk factors in patients with ESCC. A high LDL level $(>3.12 \mathrm{mmol} / \mathrm{l})$ was associated with sex $(\mathrm{P}=0.001)$, tumor location $(\mathrm{P}=0.004)$ and a higher susceptibility to lymphatic metastasis $(\mathrm{P}=0.007)$. A CCK8 assay demonstrated that LDL promoted TE-1 and ECa109 cell proliferation, and flow cytometry analysis revealed that treatment with LDL at an appropriate concentration resulted in an accumulation of cells in G2 phase and decreased the number of cells in G1 phase. In summary, the current study identified that preoperative LDL serum level serves an important role in predicting ESCC outcome as LDL promotes lymphatic metastasis. Furthermore, a preliminary mechanism for this association has been validated in vitro.

\section{Introduction}

Esophageal cancer is the eighth most commonly diagnosed cancer type in the world and the sixth leading cause of cancer-associated cases of mortality (1). Esophageal squamous cell carcinoma (ESCC) is the most predominant pathological type of esophageal cancer, accounting for $90 \%$ of all esophageal cancer cases in the developing world $(2,3)$. In addition, ESCC has been classified as the most typical esophageal tumor type by the National Health and Family Planning Commission of the People's Republic of China (3). Although the current standard treatment for patients with ESCC is an esophagectomy and adjuvant chemoradiation, the overall 5 -year survival rate is only approximately $17 \%$ due to the risks associated with this treatment (2). In addition, the prognosis for patients with an equivalent stage of ESCC varies markedly (4). A selection of serum biomarkers has previously been identified to predict the survival rate of patients with ESCC; however, the limited sensitivity and specificity of these markers, including squamous cell carcinoma antigen, cytokeratin 19 fragments and carcinoembryonic antigen, have restricted their clinical use (5-7). Therefore, novel predictive 
biomarkers, which may also promote targeted therapy for ESCC, are required.

Abdominal obesity and lipid levels are closely associated with the occurrence of esophageal cancer and several other tumor types (8-11), and high levels of lipids in serum and cell membranes are associated with the prognosis of multiple tumor types (12-14). A previous study demonstrated that total cholesterol (TC) is a good predictive marker for grading tumor regression in patients with locally advanced colorectal cancers previously treated with neoadjuvant chemoradiotherapy (15). High-density lipoprotein (HDL) is a risk factor and a prognostic factor in prostate cancer, and a decrease in HDL levels is associated with poor survival among patients with non-small-cell lung carcinoma $(6,13)$. Additionally, apolipoprotein A1, a major component of HDL, is considered to be a predictive biomarker of survival rate in patients with ESCC (14). Low-density lipoprotein (LDL) has also been implicated in ESCC (14), but a negative association has been reported in other studies (16). Regardless, the major receptor of LDL, lectin-like oxidized low-density lipoprotein (LOX-1) is a verified significant prognostic factor for multiple cancer types (17-20). To date, a few studies have focused on the prognostic role of triglyceride (TG) levels in breast cancer (21).

To clarify the prognostic value of lipid profiles in ESCC, the current study retrospectively investigated preoperative TC, HDL, LDL and TG levels in 242 patients with ESCC and analyzed associations between these levels and overall survival (OS). Additionally, the current study performed in vitro experiments to preliminarily explore a possible mechanism based on these associations.

\section{Materials and methods}

Study patients. A total of 250 eligible patients with ESCC who underwent an esophagectomy at Shandong Cancer Hospital (Jinan, China) between April 2012 and October 2014 were included in the current study. The inclusion criteria were as follows: i) Patients were previously diagnosed with ESCC and received radical surgery; ii) TC, TG, HDL and LDL levels were examined 2-5 days prior to surgery between 6:00 and 8:00 a.m. using a Modular p800 analyzer (Roche Diagnostics, Basel, Switzerland); and iii) no drugs known to affect lipids, including statins, were taken by the patients. Exclusion criteria were as follows: i) History of another cancer type; ii) diabetes or another endocrine or metabolic disease that may influence serum lipid levels; and iii) cachexia [body mass index (BMI) $\left.<20 \mathrm{~kg} / \mathrm{m}^{2}\right]$.

Follow-up assessment. Follow-up assessments were performed annually by telephone interviews and review of medical records. This was performed every 2 months for patients with evidence of distant metastasis and local recurrence. The last follow-up was completed in October 2016. The endpoint of the current study was OS, which was defined as the time interval between diagnosis and mortality or the last follow-up. Survivors were defined as alive at the time of the last follow-up, whereas non-survivors were defined as having died at any time during the study. Tumor and clinical characteristics of the patients, including age, sex, Pathological N-staging status (pT status), Pathological N-staging status (pN status), grade and histological type, were obtained from medical records and pathology reports.

The current study was approved by the Institutional Review Board of Shandong Cancer Hospital. Informed consent and survival status were verified through direct telecommunication with the patients or their families.

Cell culture. Esophageal cancer cell lines TE-1 and ECa109 were obtained from the Cell Bank of the Chinese Academy of Sciences (Institute of Shanghai Cell Biology and Chinese Type Culture Collection, Shanghai, China). ECa109 cells were grown in RPMI-1640 and TE-1 cells were maintained in Dulbecco's modified Eagle's medium supplemented with $10 \%$ fetal bovine serum (all from Hyclone; GE Healthcare, Logan, UT, USA). All cells were grown at $37^{\circ} \mathrm{C}$ in humidified air containing $5 \% \mathrm{CO}_{2}$.

Cell viability detection via the Cell Counting Kit-8 (CCK8) assay and cell cycle analysis by flow cytometry. TE-1 and ECa109 cells were seeded in 96 -well plates at $3.0 \times 10^{3} /$ well and maintained for $24 \mathrm{~h}$ until attachment at $37^{\circ} \mathrm{C}$ in a humidified, $5 \% \mathrm{CO}_{2}, 95 \%$ air atmosphere. The cells were then starved with serum-free medium for $4 \mathrm{~h}$ and incubated with various concentrations of $\operatorname{LDL}(0,10,50,100,200$ and $400 \mu \mathrm{g} / \mathrm{ml}$; Thermo Fisher Scientific, Inc., Waltham, MA, USA) for 24, 48 and $72 \mathrm{~h}$ at $37^{\circ} \mathrm{C}$ in a humidified, $5 \% \mathrm{CO}_{2}$. To determine the effects of LDL, TE-1 and ECa109 cell viability was measured using the CCK8 assay according to the manufacturer's protocol (Dojindo Molecular Technologies, Inc., Kumamoto, Japan) and the cell cycle was detected by Propidium lodide (PI)/RNase Staining Buffer (BD Biosciences, Franklin Lakes, NJ, USA) and analyzed by flow cytometry with Modfit LT 4.0 (Verity Software House, Topsham, ME, USA).

Statistical analysis. Statistical analyses were performed with SPSS 21.0 software (IBM Corp., Armonk, NY, USA). Serum lipid levels were expressed as the mean \pm standard deviation. Univariate and multivariate analyses were performed using Kaplan-Meier and Cox proportional hazards regression models to determine associations between OS, the clinical parameters and the TC, HDL, LDL and TG levels. The hazard ratio (HR) was reported as the relative risk with $95 \%$ confidence intervals. Associations between the serum lipids and clinical characteristics were determined with the $\chi^{2}$ test or univariate analysis. Survival curves were plotted on the basis of the aforementioned results and the curves were compared using the log-rank test. All P-values were two-sided and $\mathrm{P}<0.05$ was considered to indicate a statistically significant difference.

\section{Results}

Patient characteristics. In the current retrospective study, follow-up of 242 patients with ESCC was completed with a success rate of $96.8 \%(242 / 250 ; 3$ patients refused to provide information and communication was lost with 5 patients). The 242 patients included 190 (78.5\%) males and $52(21.5 \%)$ females, with a median age of 61 years (range, 35-80 years). The disease characteristics were as follows: $20(8.3 \%)$ patients had upper thoracic esophageal cancer, $128(52.9 \%)$ had middle thoracic esophageal cancer and 94 (38.8\%) had 
Table I. Univariate and multivariate analysis for overall survival in patients with esophageal squamous cell carcinoma.

\begin{tabular}{|c|c|c|c|c|c|c|}
\hline \multirow[b]{2}{*}{ Variables } & \multirow[b]{2}{*}{$\mathrm{n}$} & \multicolumn{2}{|c|}{ Univariate analysis } & \multicolumn{3}{|c|}{ Multivariate analysis } \\
\hline & & $\chi^{2}$ & P-value & $\beta$ & HR & P-value \\
\hline Age & & 0.024 & 0.876 & & & \\
\hline$<60$ & 114 & & & & & \\
\hline$\geq 60$ & 128 & & & & & \\
\hline Sex & & 3.617 & 0.057 & & & \\
\hline Male & 190 & & & & & \\
\hline Female & 52 & & & & & \\
\hline Tumor location & & 5.745 & 0.056 & & & \\
\hline Upper & 20 & & & & & \\
\hline Middle & 128 & & & & & \\
\hline Lower & 94 & & & & & \\
\hline Histological differentiation & & 12.615 & 0.002 & 1.407 & 4.083 & 0.002 \\
\hline Well & 60 & & & & & \\
\hline Moderate & 122 & & & & & \\
\hline Low & 60 & & & & & \\
\hline pT status & & 27.277 & 0.001 & 0.539 & 1.714 & 0.001 \\
\hline $\mathrm{T} 1$ & 19 & & & & & \\
\hline $\mathrm{T} 2$ & 28 & & & & & \\
\hline $\mathrm{T} 3$ & 158 & & & & & \\
\hline $\mathrm{T} 4$ & 37 & & & & & \\
\hline pN status & & 71.184 & 0.001 & 0.676 & 1.966 & 0.001 \\
\hline N0 & 110 & & & & & \\
\hline $\mathrm{N} 1$ & 94 & & & & & \\
\hline $\mathrm{N} 2$ & 29 & & & & & \\
\hline N3 & 9 & & & & & \\
\hline $\mathrm{TC}, \mathrm{mmol} / \mathrm{l}$ & & 0.878 & 0.349 & & & \\
\hline$>5.2$ & 72 & & & & & \\
\hline$\leq 5.2$ & 170 & & & & & \\
\hline $\mathrm{TG}, \mathrm{mmol} / \mathrm{l}$ & & 2.843 & 0.096 & & & \\
\hline$>1.7$ & 32 & & & & & \\
\hline$\leq 1.7$ & 210 & & & & & \\
\hline LDL, mmol/1 & & 5.454 & 0.02 & 0.722 & 2.164 & 0.005 \\
\hline$>3.12$ & 44 & & & & & \\
\hline$\leq 3.12$ & 198 & & & & & \\
\hline $\mathrm{HDL}, \mathrm{mmol} / \mathrm{l}$ & & 3.914 & 0.048 & 0.063 & 0.939 & 0.757 \\
\hline$>1.42$ & 74 & & & & & \\
\hline$\leq 1.42$ & 168 & & & & & \\
\hline
\end{tabular}

HR, hazard ratio; TC, total cholesterol; TG, triglyceride; LC, lipoprotein cholesterol; LDL, low-density lipoprotein; HDL, high-density lipoprotein; n, number; $\beta, \beta$-coefficient; pT status, Pathological T-staging status; pT status, Pathological N-staging status.

low thoracic esophageal cancer. Histologically well-differentiated disease, moderately differentiated disease and poorly differentiated disease were identified in 60 (24.8\%), $122(50.4 \%)$ and $60(24.8 \%)$ patients, respectively. Among the patients, $19(7.8 \%)$ had stage T1 disease, 28 (11.6\%) had stage T2 disease, $158(65.3 \%)$ had stage T3 disease and 37 $(15.3 \%)$ had stage T4 disease. Regarding staging, $110(45.5 \%)$ patients demonstrated stage N0 disease, 94 (38.8\%) stage
$\mathrm{N} 1$ disease, 29 (12.0\%) stage N2 disease and 9 (3.7\%) N3 disease (Table I).

The mean values of serum lipid levels prior to therapy were as follows: $\mathrm{TC}=4.72 \pm 0.89 \mathrm{mmol} / \mathrm{l}, \mathrm{TG}=1.10 \pm 0.57 \mathrm{mmol} / \mathrm{l}$, $\mathrm{LDL}=2.63 \pm 0.56 \mathrm{mmol} / \mathrm{l}$ and $\mathrm{HDL}=1.30 \pm 0.38 \mathrm{mmol} / \mathrm{l}$ (Table II).

LDL, pT status, pN status and histological differentiation are independent prognostic factors in patients with ESCC. 
Table II. Lipid levels and association with overall survival.

\begin{tabular}{lccccr}
\hline Serum lipid & Min, $\mathrm{mmol} / \mathrm{l}$ & Max, $\mathrm{mmol} / \mathrm{l}$ & Mean $\pm \mathrm{SD}, \mathrm{mmol} / \mathrm{l}$ & HR & P-value \\
\hline TC & 2.84 & 7.12 & $4.72 \pm 0.89$ & 1.096 & 0.319 \\
TG & 0.49 & 5.16 & $1.10 \pm 0.57$ & 1.057 & 0.724 \\
LDL & 1.63 & 5.16 & $2.63 \pm 0.56$ & 2.164 & 0.005 \\
HDL & 0.57 & 2.94 & $1.30 \pm 0.38$ & 0.939 & 0.757
\end{tabular}

TC, total cholesterol; TG, triglyceride; LDL, low-density lipoprotein; HDL, high-density lipoprotein; min, minimum; max, maximum; HR, hazard ratio; SD, standard deviation.

The $\chi^{2}$ test, Kaplan-Meier analysis and Cox regression model were applied to characterize the association between prognosis and serum lipid levels or clinical parameters, including age, sex, tumor location, histological differentiation, pT status and pN status, in patients with ESCC (Table I). Univariate survival analysis revealed significant associations between poor survival and HDL $\left(\chi^{2}=3.914, \mathrm{P}=0.048\right)$, LDL $\left(\chi^{2}=5.454, \mathrm{P}=0.020\right)$, pT status (T1-2 vs. T3-4; $\chi^{2}=27.277$, $\mathrm{P}=0.001$ ), $\mathrm{pN}$ status (N0 vs. N1-3; $\chi^{2}=71.184, \mathrm{P}=0.001$ ) and histological differentiation $\left(\chi^{2}=12.615, \mathrm{P}=0.002\right)$, whereas the other clinical features investigated in the current study demonstrated no association with OS. Multivariate survival analysis was performed to clarify the independent prognostic values of these five factors, with $\mathrm{LDL}(\mathrm{HR}=2.164, \mathrm{P}=0.005)$, histological differentiation $(\mathrm{HR}=4.083, \mathrm{P}=0.002)$, pT status $(\mathrm{HR}=1.714, \mathrm{P}=0.001)$ and $\mathrm{pN}$ status $(\mathrm{HR}=1.966, \mathrm{P}=0.001)$ demonstrating an association with ESCC prognosis. Survival curves were then generated based on these results. The 3-year survival rate of patients with ESCC with lower LDL levels ( $\leq 3.12 \mathrm{mmol} / \mathrm{l}$ ) was $34.7 \%$, compared with $15.8 \%$ for patients with higher LDL levels (>3.12 mmol/l; Fig. 1A). Additionally, a higher $\mathrm{pT}$ status and $\mathrm{pN}$ status were associated with a poor 3-year survival rate in patients with ESCC (T1-2 vs. T3-4, 45.5 vs. $27.1 \%$; N0 vs. N1-3, 50.9 vs. $13.8 \%$; Fig. $1 \mathrm{~B}$ and C), as was histological differentiation (high-differentiated disease vs. low vs. moderate differentiation, $56.7 \%$ vs. $24.6 \%$ vs. $23.2 \%$; Fig. 1D). Therefore, the current study identified that pre-therapy serum LDL level may be a significant prognostic factor for patients with ESCC.

Associations between LDL levels and other clinical characteristics. The observed associations between different levels of LDL and other clinical features are presented in Table III. Statistical analysis identified that the LDL level was significantly associated with sex $(\mathrm{P}=0.001)$, tumor location $(\mathrm{P}=0.004)$ and $\mathrm{pN}$ status $(\mathrm{P}=0.007)$. However, no significant associations were evident between the LDL level and the other parameters investigated in the current study.

Effect of LDL on cell proliferation. As demonstrated in Fig. 2A, TE-1 cell proliferation was promoted by LDL; the proliferation level increased as the LDL treatment time increased and as the LDL concentration increased $(\mathrm{P}<0.05)$. However, the proliferation level declined when the LDL concentration exceeded $200 \mu \mathrm{g} / \mathrm{ml}$. This finding indicated that an appropriate LDL concentration may promote esophageal carcinoma cell growth. TE-1 cells exhibited the largest proliferation efficiency when treated with $200 \mu \mathrm{g} / \mathrm{ml} \mathrm{LDL}$ for $72 \mathrm{~h}$. The growth characteristics of ECa109 cells were equivalent to those of TE-1 cells (Fig. 2B).

Effect of LDL on cell cycle distribution. The cell cycle was also analyzed to confirm the promoting effect of LDL on esophageal carcinoma cell proliferation. TE-1 and ECa109 cells were incubated with different concentrations of $\operatorname{LDL}(0,50,100$ and $200 \mu \mathrm{g} / \mathrm{ml}$ ) for $72 \mathrm{~h}$ and then collected for cell cycle analysis. As demonstrated in Fig. 3, the percentage of G1-phase TE-1 cells decreased from 73.05 to $40.08 \%$ in response to LDL, with a corresponding increase in the total proportion of $\mathrm{S}$ and G2-phase cells from 26.95 to $59.92 \%$. These data indicated that proliferation was induced by LDL in TE-1 cells. Similar results were obtained with ECa109 cells, whereby the G1-phase proportion decreased from 63.91 to $51.83 \%$ and the total proportion of S and G2 phase cells increased from 36.09 to $48.17 \%$ in response to LDL (Fig. 4).

\section{Discussion}

The preoperative serum lipid levels of patients with ESCC were evaluated in the current study. Operable patients were selected because they had well-defined disease stages and good nutrition statuses, which may avoid abnormal blood lipid levels caused by dystrophia. In addition, BMI and serum albumin levels were comparable between the higher LDL group and lower LDL group (data not shown). Therefore, in the current study, preoperative serum lipid levels were considered to be independent of nutritional status. The number of male patients was more than three times that of female patients (190 vs. 52). In China, there is a significant sex difference in the incidence of esophageal cancer and the proportion of men and women included in the current study is consistent with the incidence (22). This predominance may be because abdominal adiposity is more common in males; abdominal adiposity increases intragastric pressure and relaxes the lower esophageal sphincter, which leads to acid reflux (23). Furthermore, males are more likely to consume alcohol and smoke cigarettes, and these factors have been suggested as the underlying reason for the higher number of males with ESCC relative to females (24).

The results of the current study demonstrate that high LDL ( $>3.12 \mathrm{mmol} / \mathrm{l})$ is positively associated with a short OS time, as are other parameters, including $\mathrm{pT}$ status, $\mathrm{pN}$ status and 
A

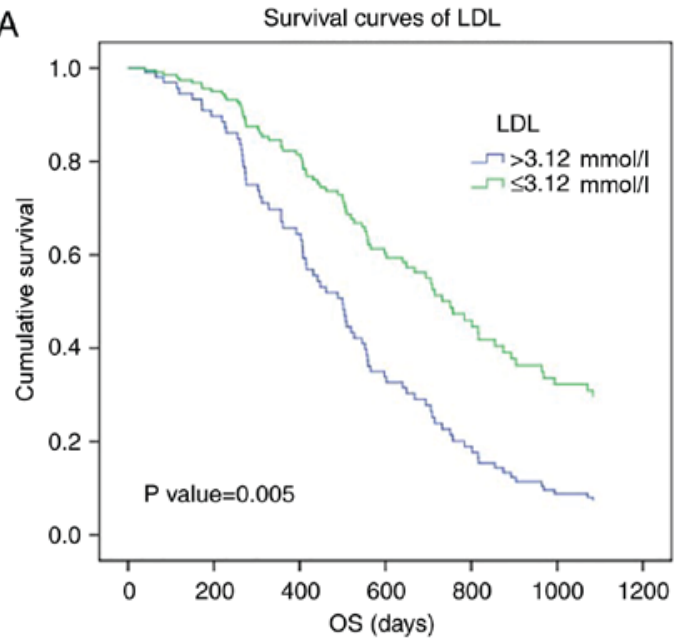

C

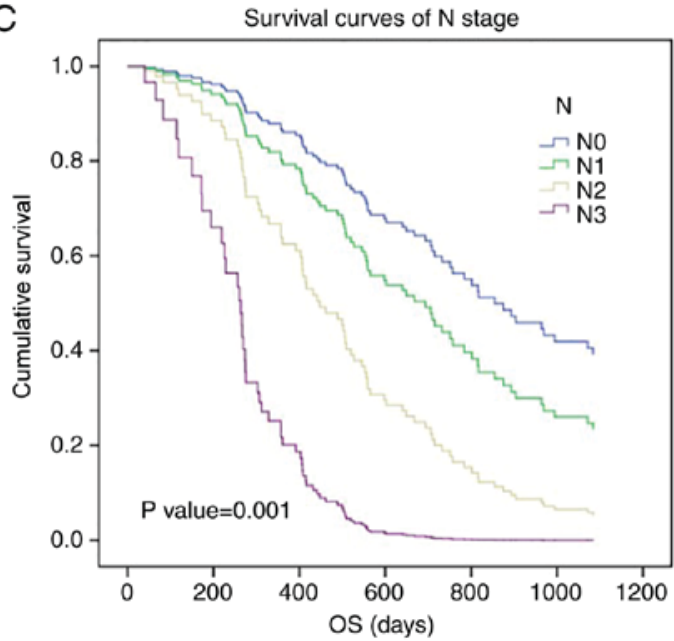

B

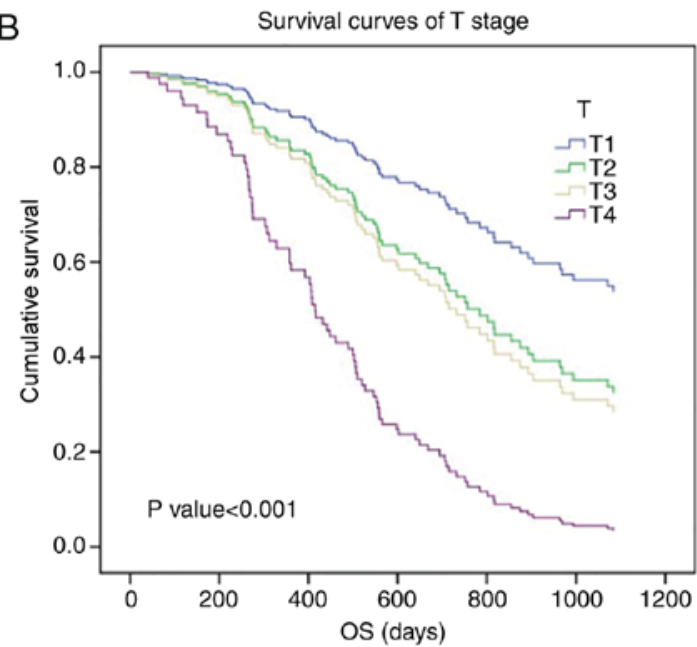

D

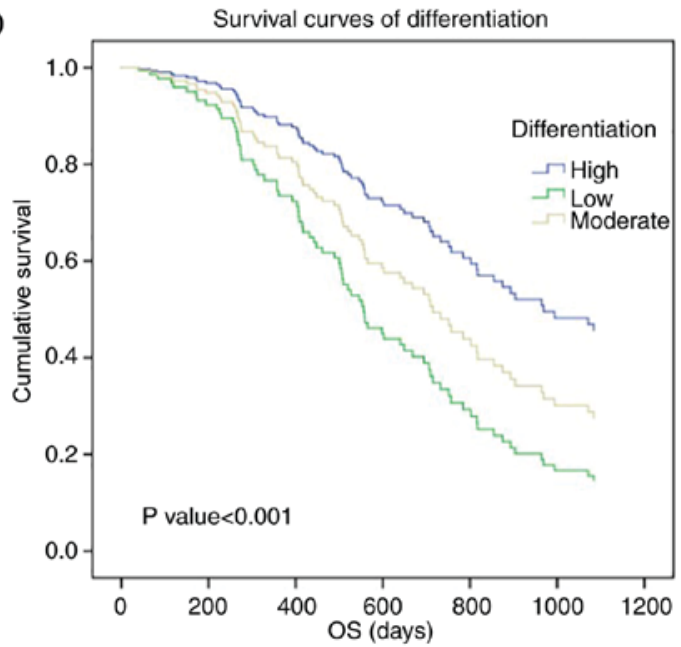

Figure 1. Prognostic significance of LDL and other clinical features in esophageal squamous cell carcinoma. (A) High LDL, (B) pT status, (C) pN status and (D) low differentiation were poor prognostic factors according to Cox survival curves. LDL, low-density lipoprotein; OS, overall survival.

histological differentiation. This association may be caused by increased lymphatic metastasis. However no significant association was identified between serum LDL level and $\mathrm{pN}$ status in a similar study (25). There may be several reasons for this; firstly, retrospective studies are prone to bias and may explain why the current study and the previous study draw different conclusions. Secondly, the research data used in the current study and the previous study were collected between 2012-2014 and 2007-2008, respectively, but both datasets are limited. In addition, the number of patients in both studies was more than 200 , this facilitates preliminary results to be obtained but a larger sample size is required for further confirmation. The authors of both studies are currently preparing to collaborate and analyze a larger sample with joint multi-centric data in the hope of obtaining more convincing results. Lastly, different patient groups were selected in the two different studies; the proportion of patients with $\mathrm{T} 3$ and $\mathrm{T} 4$ stage disease in the current study was as high as $80.4 \%$, whereas this number was $61.7 \%$ in the previous study. Differences in the stage of ESCC may affect the nutritional status of patients and cause a decrease in blood lipid levels.

Several previous studies have also suggested there is a significant association between LDL levels and cancer prognosis. Zhou et al (26) demonstrated that LDL is a prognostic index for the survival of patients with small-cell lung cancer and Rodrigues et al (27) indicated that the LDL level is associated with disease-free survival in patients with breast cancer. In patients with prostate cancer, preoperative LDL cholesterol is an independent predictor of recurrence (28) and LDL is also an independent prognostic factor for patients with colorectal cancer (29). Additionally, in the current study, the LDL level demonstrated an independent association with the $\mathrm{pN}$ status of ESCC, which was consistent with the research conclusion of the current study (Table III). Sako et al (30) also identified that hyperlipidemia is a risk factor for lymphatic metastasis in superficial esophageal carcinoma, which supports the conclusion made by the current study.

Several years ago, multiple studies supported the view that exogenous LDL promoted the proliferation of breast cancer and colon adenocarcinoma cells $(31,32)$. The results of the current study, which are based on cell viability assays and cell cycle analysis, support a similar conclusion in esophageal cancer cells. To the best of our knowledge, the current study is the first to demonstrate that LDL enhances the growth rate of esophageal cancer cells in vitro. This observation may be attributed to the possible involvement of the LDL receptor-related protein 1 (LRP1) in regulating cancer cell survival and metastatic potential, which occurs through the ability of LDL to promote 
Table III. Clinical patient characteristics according to the LDL level.

\begin{tabular}{|c|c|c|c|c|}
\hline Characteristic & $\mathrm{LDL}>3.12 \mathrm{mmol} / \mathrm{l}, \mathrm{n}(\mathrm{n}=44)$ & $\mathrm{LDL} \leq 3.12 \mathrm{mmol} / \mathrm{l}, \mathrm{n}(\mathrm{n}=198)$ & $\chi^{2}$ & P-value \\
\hline Age & & & 1.4114 & 0.234 \\
\hline$<60$ & 16 & 94 & & \\
\hline$\geq 60$ & 28 & 104 & & \\
\hline Sex & & & 25.11 & 0.001 \\
\hline Male & 20 & 165 & & \\
\hline Female & 22 & 33 & & \\
\hline Tumor location & & & 10.90 & 0.004 \\
\hline Upper & 10 & 11 & & \\
\hline Middle & 20 & 109 & & \\
\hline Lower & 14 & 78 & & \\
\hline HD & & & 0.506 & 0.777 \\
\hline Well & 10 & 54 & & \\
\hline Moderate & 22 & 99 & & \\
\hline Low & 12 & 45 & & \\
\hline pT status & & & 5.566 & 0.135 \\
\hline $\mathrm{T} 1-2$ & 11 & 36 & & \\
\hline $\mathrm{T} 3-4$ & 33 & 162 & & \\
\hline pN status & & & 12.156 & 0.007 \\
\hline N0 & 18 & 87 & & \\
\hline N1-3 & 26 & 111 & & \\
\hline
\end{tabular}

LDL, low-density lipoprotein; HD, Histological differentiation; n, number; pT status, Pathological T-staging status; pT status, Pathological $\mathrm{N}$-staging status.
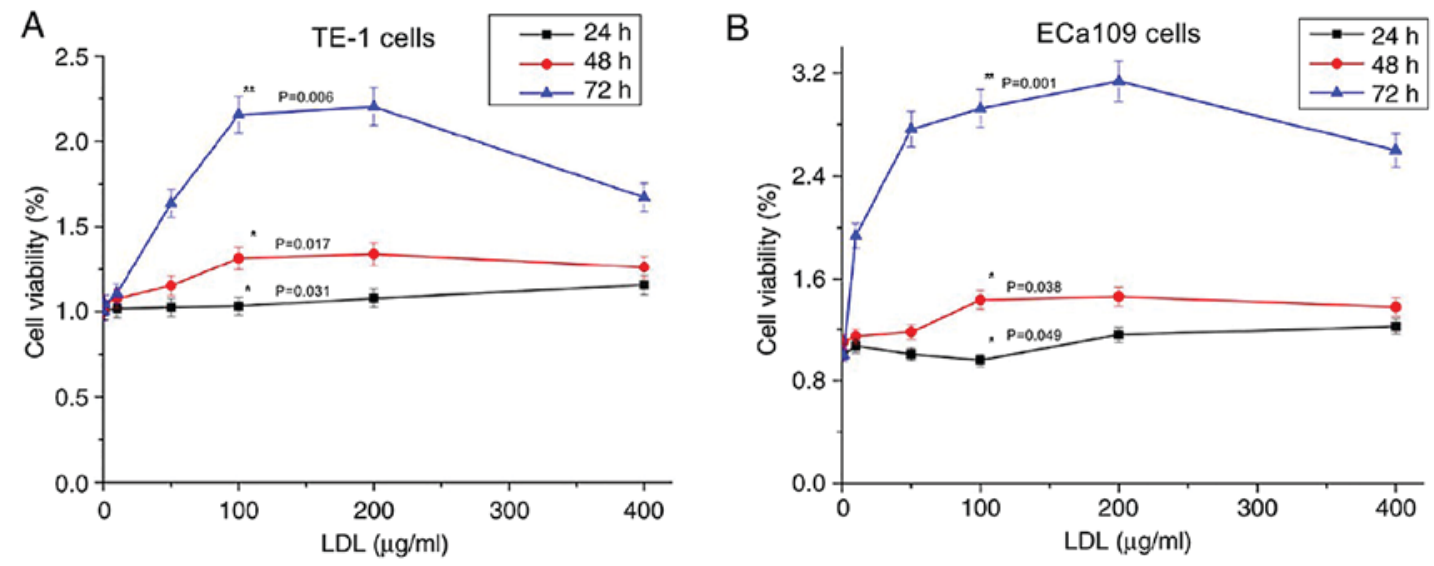

Figure 2. Effect of LDL on TE-1 and ECa109 esophageal cancer cell viability. Cells were incubated with various concentrations of LDL (0-400 $\mu \mathrm{g} / \mathrm{ml})$ for $24 \mathrm{~h}$ (black line), $48 \mathrm{~h}$ (red line) and $72 \mathrm{~h}$ (blue line). (A) The TE-1 proliferation rate increased with the treatment time and with a concentration $<200 \mu \mathrm{g} / \mathrm{ml}$; the proliferation rate decreased with LDL concentrations between 200 and $400 \mu \mathrm{g} / \mathrm{ml}\left({ }^{*} \mathrm{P}<0.05 \mathrm{vs} .24 \mathrm{~h} ;{ }^{*} \mathrm{P}<0.05 \mathrm{vs} .48 \mathrm{~h}\right.$; ${ }^{* * *} \mathrm{P}<0.01 \mathrm{vs}$. $72 \mathrm{~h}$ ). (B) Similar results were obtained using ECa109 cells ( ${ }^{*} \mathrm{P}<0.05$ vs. $24 \mathrm{~h} ;{ }^{*} \mathrm{P}<0.05$ vs. $48 \mathrm{~h} ;{ }^{* *} \mathrm{P}<0.01$ vs. $\left.72 \mathrm{~h}\right)$. LDL, low-density lipoprotein.

cancer cell proliferation and differentiation $(30,33)$. This hypothesis requires a more detailed investigation.

Although the findings of the current study provide evidence of a preliminary mechanism through our in vitro analysis, the intrinsic mechanism by which LDL promotes cell development is unclear. Several interesting studies have suggested that many factors may explain the findings to date. Firstly, migration and invasion of tumor cells is partially dependent on exogenous LDL cholesterol and is possibly driven through LDL-related receptors $(34,35)$. LOX-1 may facilitate the proliferation of gastric cancer cells by driving the epithelial-mesenchymal transition and phosphoinositide 3-kinase/Akt/glycogen synthase kinase $\beta$ activation (34). Additionally, low-density lipoprotein receptor serves an important role in tumor cancer growth and invasion by regulating nuclear factor $\kappa$-light-chain enhancer of activated B cells signaling, and this serves as a prognostic index in patients with small cell lung cancer $(26,36)$. Furthermore, LRP1 may contribute to the ability of cancer 
A
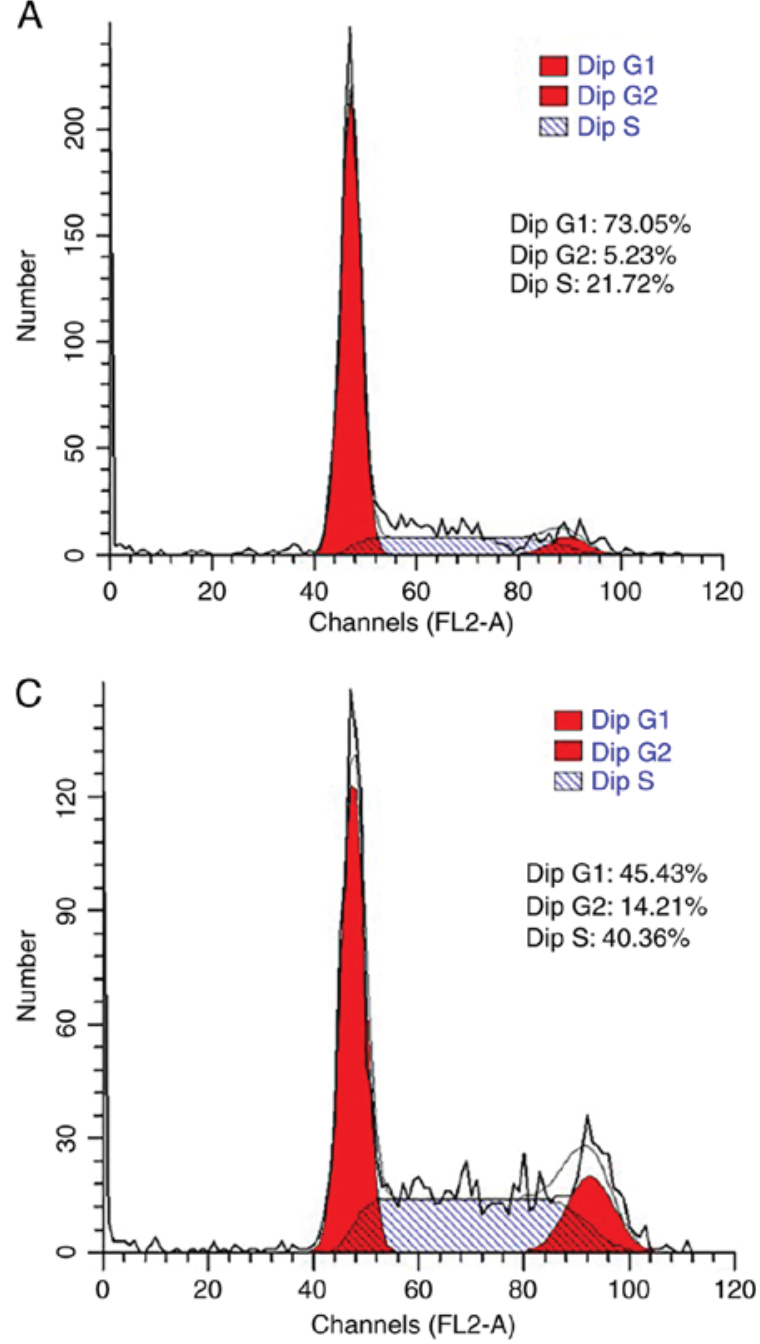
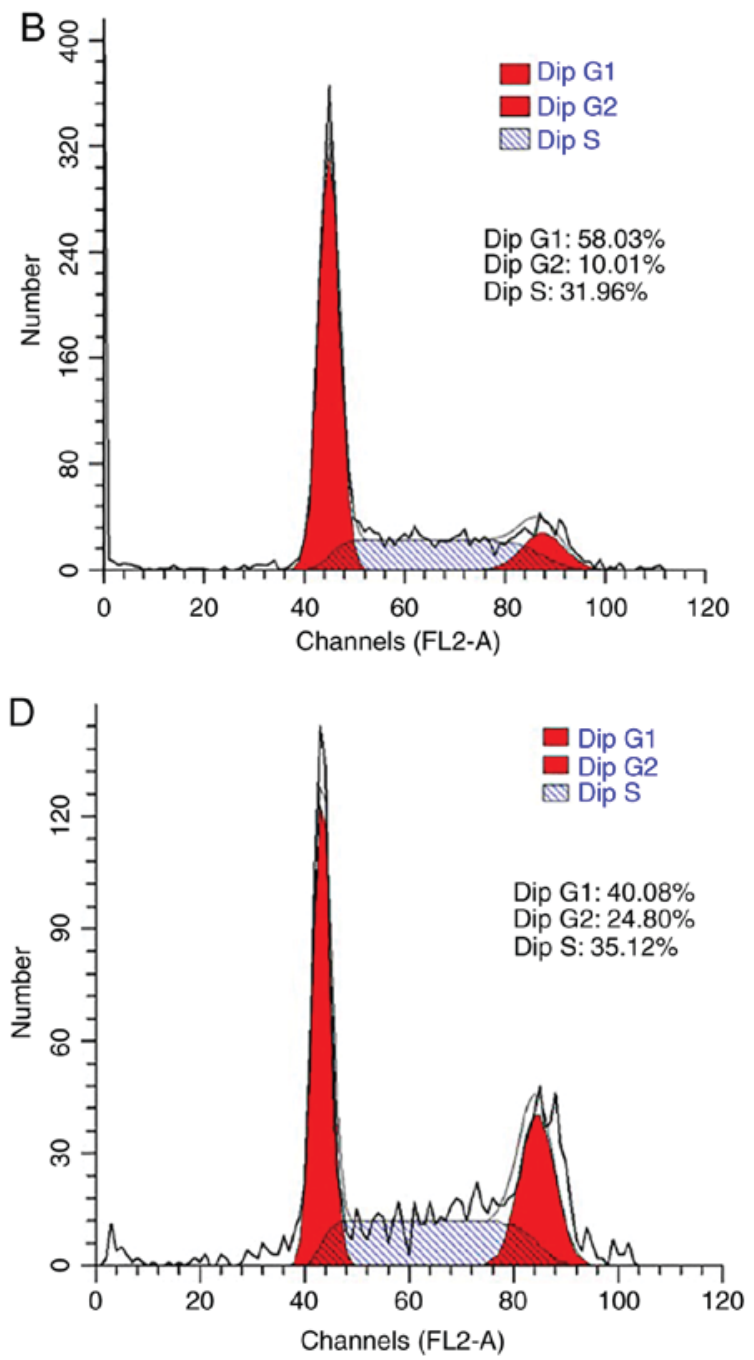

Figure 3. Effect of LDL on the TE-1 cell cycle distribution. Cells were incubated with various concentrations of LDL; (A) $0 \mu \mathrm{g} / \mathrm{ml},(\mathrm{B}) 50 \mu \mathrm{g} / \mathrm{ml},(\mathrm{C}) 100 \mu \mathrm{g} / \mathrm{ml}$ and (D) $200 \mu \mathrm{g} / \mathrm{ml}$ for $72 \mathrm{~h}$ and the percentage of cells in each phase of the cell cycle was determined by flow cytometry. LDL, low-density lipoprotein; dip, diploid.

cells to form large metastases via increased expression of vascular endothelial cell growth factor (VEGF) and reduced cell death in response to hypoxia (33); tumor invasion is promoted via stimulation of the extracellular signal-regulated kinase pathway and inhibition of the c-Jun N-terminal kinase pathway (35).

Similar to the study by Montel et al (33), the addition of LDL cholesterol may induce activation of microvascular endothelial cells, which facilitates lymph node metastases of colon cancer cells (31). Additionally, Lu et al (37) demonstrated that L5, a cytokine through which LDL induces endothelial apoptosis, increases secretion of an angiogenic factor, amphiregulin, by breast cancer cells and promotes progression and metastasis (37). Other inflammatory cytokines, including L1 and tumor necrosis factor, can also promote progression and metastasis, which may induce hyper-adhesion to vascular endothelial cells and augment tumor arrest and metastasis $(38,39)$.

Furthermore, suppressive effects on the function of immune cells may be another mechanism through which a high LDL level enhances tumor metastasis. LRP1-deficient myeloid cells may allow tumor-associated macrophages to provide increased amounts of VEGF to a tumor (40). McCarthy et al (41) reported that a high LDL level inhibits T cell proliferation and macrophage tumoricidal activity may be decreased by a high-fat diet in mice (42).

Based on these speculations and the results of the current study, it can be proposed that LDL is a prognostic factor in patients with ESCC because it promotes lymphatic metastasis. Although the intrinsic mechanism is unclear, a high level of LDL has an apparent role in promoting growth of TE-1 and ECa109 esophageal cancer cells. However, the current study has several limitations. Firstly, this was a retrospective study and not a prospective study. Additionally, patients from only one institution were recruited and only 242 patients were included. Future studies may involve more patients from multiple centers and the detailed mechanism of the effect of LDL on esophageal carcinoma cells may be investigated further

In summary, the LDL level is an adverse prognostic factor for ESCC. Additionally, LDL is an economical and convenient biomarker that may support clinical needs. Furthermore, to the best of our knowledge, the current study is the first to hypothesize that a high LDL level is associated with poor OS because LDL promotes lymphatic metastasis and this hypothesis has been partially confirmed in vitro. A more detailed mechanism is required to be investigated in future studies. 

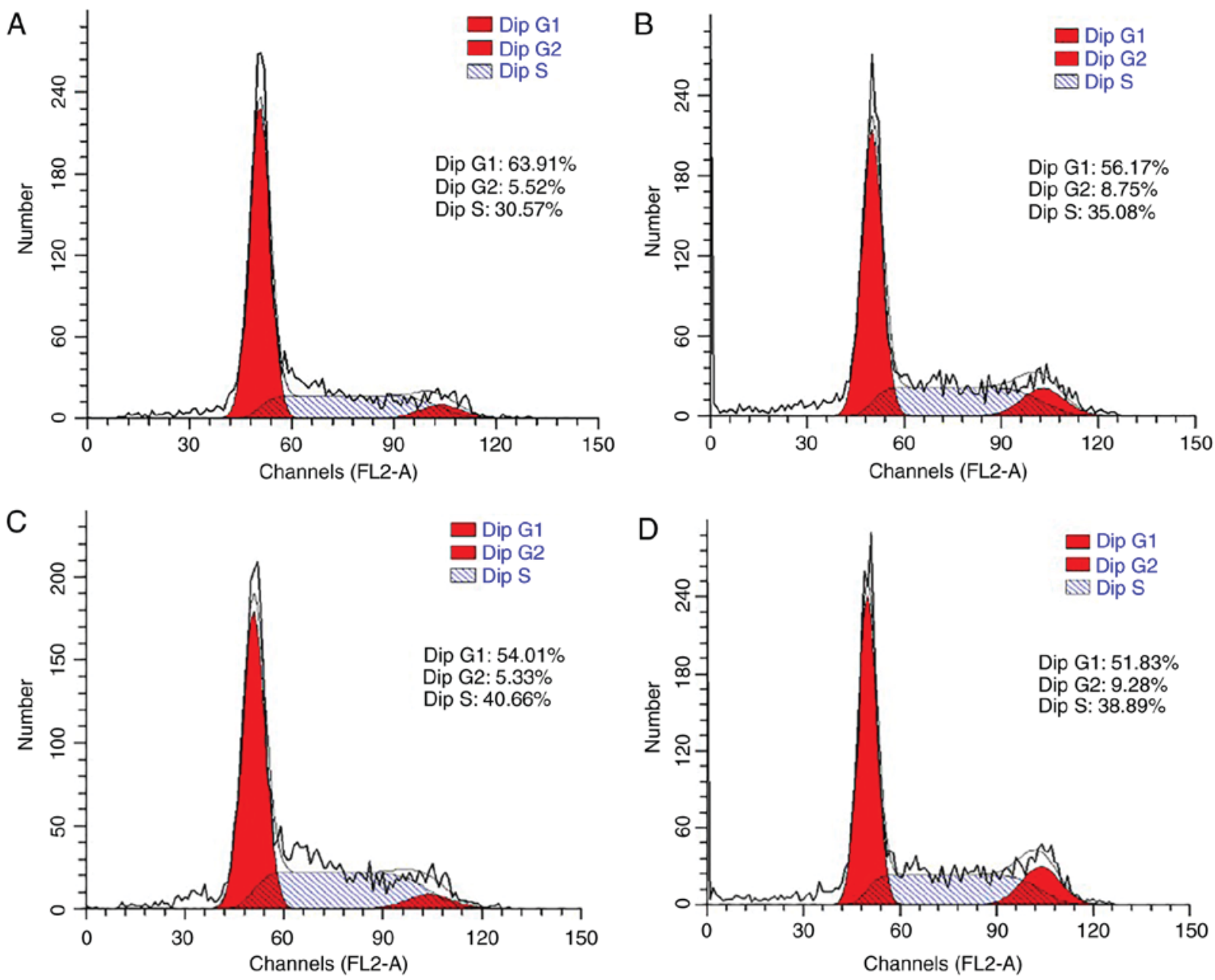

Figure 4. Effect of LDL on the ECa109 cell cycle distribution. Cells were incubated with various concentrations of LDL; (A) $0 \mu \mathrm{g} / \mathrm{ml}$, (B) $50 \mu \mathrm{g} / \mathrm{ml}$, (C) $100 \mu \mathrm{g} / \mathrm{ml}$ and (D) $200 \mu \mathrm{g} / \mathrm{ml}$ for $72 \mathrm{~h}$ and the percentage of cells in each phase of the cell cycle was determined by flow cytometry. LDL, low-density lipoprotein; dip, diploid.

\section{Acknowledgements}

Not applicable.

\section{Funding}

The current study was supported by the National Natural Science Foundation of China (grant nos. 81301936 and 81472811) and the Science Technology Development Project of Shandong Province (grant nos. 2014GGC03038 and ZR2013HM080).

\section{Availability of data and materials}

The datasets used and analyzed during the current study are available from the corresponding author on reasonable request.

\section{Authors' contributions}

CL and TZ participated in study design. HD, YY and CL carried out the experiments and the data analysis. XM was responsible for the implementation of cell experiments. $\mathrm{TZ}$ and YY participated in data discussion and revision of the manuscript. All authors read and approved the final manuscript.

\section{Ethics approval and consent to participate}

The current study was approved by the Institutional Review Board of Shandong Cancer Hospital. Informed consentwas verified through direct telecommunication with the patients or their families.

\section{Patient consent for publication}

Not applicable.

\section{Competing interests}

The authors declare that they have no competing interests.

\section{References}

1. Pennathur A, Gibson MK, Jobe BA and Luketich JD: Oesophageal carcinoma. Lancet 381: 400-412, 2013.

2. Rustgi AK and El-Serag HB: Esophageal carcinoma. N Engl J Med 371: 2499-2509, 2014.

3. Tran GD, Sun XD, Abnet CC, Fan JH, Dawsey SM, Dong ZW, Mark SD, Qiao YL and Taylor PR: Prospective study of risk factors for esophageal and gastric cancers in the Linxian general population trial cohort in China. Int J Cancer 113: 456-463, 2005. 
4. Van Hagen P, Hulshof MC, van Lanschot JJ, Steyerberg EW, van Berge Henegouwen MI, Wijnhoven BP, Richel DJ, Nieuwenhuijzen GA, Hospers GA, Bonenkamp JJ, et al: Preoperative chemoradiotherapy for esophageal or junctional cancer. N Engl J Med 366: 2074-2084, 2012

5. Zheng X, Xing S, Liu XM, Liu W, Liu D, Chi PD, Chen H, Dai SQ, Zhong Q, Zeng MS, et al: Establishment of using serum YKL-40 and SCCA in combination for the diagnosis of patients with esophageal squamous cell carcinoma. BMC Cancer 14: 490 , 2014.

6. Cao HH, Zhang SY, Shen JH, Wu ZY, Wu JY, Wang SH, Li EM and Xu LY: A three-protein signature and clinical outcome in esophageal squamous cell carcinoma. Oncotarget 6: 5435-5448, 2015.

7. Chen GQ, Tian H, Yue WM, Li L, Li SH, Qi L, Gao C, Si LB and $\mathrm{Lu} \mathrm{M}$ : NCOA5 low expression correlates with survival in esophageal squamous cell carcinoma. Med Oncol 31: 376, 2014.

8. Gupta A, Das A, Majumder K, Arora N, Mayo HG, Singh PP, Beg MS and Singh S: Obesity is independently associated with increased risk of hepatocellular cancer-related mortality: A systematic review and meta-analysis. Am J Clin Oncol 49: 874-881, 2018

9. Chang SJ, Hou MF, Tsai SM, Wu SH, Hou LA, Ma H, Shann TY, Wu SH and Tsai LY: The association between lipid profiles and breast cancer among Taiwanese women. Clin Chem Lab Med 45 $1219-1223,2007$.

10. Zhang X, Zhao XW, Liu DB, Han CZ, Du LL, Jing JX and Wang Y: Lipid levels in serum and cancerous tissues of colorectal cancer patients. World J Gastroenterol 20: 8646-8652, 2014

11. Duggan C, Onstad L, Hardikar S, Blount PL, Reid BJ and Vaughan TL: Association between markers of obesity and progression from Barrett's esophagus to esophageal adenocarcinoma. Clin Gastroenterol Hepatol 11: 934-943, 2013.

12. Pelton K, Freeman MR and Solomon KR: Cholesterol and prostate cancer. Curr Opin Pharmacol 12: 751-759, 2012.

13. Chi PD, Liu W, Chen H, Zhang JP, Lin Y, Zheng X, Liu W and Dai S: High-density lipoprotein cholesterol is a favorable prognostic factor and negatively correlated with $\mathrm{C}$-reactive protein level in non-small cell lung carcinoma. PLoS One 9: e91080, 2014

14. Wang XP, Li XH, Zhang L, Lin JH, Huang H, Kang T, Mao MJ, Chen $\mathrm{H}$ and Zheng X: High level of serum apolipoprotein A-I is a favorable prognostic factor for overall survival in esophageal squamous cell carcinoma. BMC Cancer 16: 516, 2016.

15. Wang Y, Liu C, Zhang J, Liu Y, Gong G, Mo X, Liu P, Li B and Yin Y: Predictive value of blood lipid association with response to neoadjuvant chemoradiotherapy in colorectal cancer. Tumour Biol 37: 4955-4961, 2016

16. Wang Y, Li H, Diao Y, Li H, Zhang Y, Yin C, Cui Y, Ma Q Fang X, Zhou Y and Yang Y: Relationship between oxidized LDL antibodies and different stages of esophageal carcinoma. Arch Med Res 39: 760-777, 2008.

17. González-Chavarría I, Cerro RP, Parra NP, Sandoval FA, Zuñiga FA, Omazábal VA, Lamperti LI, Jiménez SP, Fernandez EA, Gutiérrez NA, et al: Lectin-like oxidized LDL receptor-1 is an enhancer of tumor angiogenesis in human prostate cancer cells. PLoS One 9: e106219, 2014.

18. Wan F, Qin X, Zhang G, Lu X, Zhu Y, Zhang H, Dai B, Shi G and Ye D: Oxidized low-density lipoprotein is associated with advanced-stage prostate cancer. Tumour Biol 36: 3573-3582, 2015.

19. Murdocca M, Mango R, Pucci S, Biocca S, Testa B, Capuano R, Paolesse R, Sanchez M, Orlandi A and di Natale C, et al: The lectin-like oxidized LDL receptor-1: A new potential molecular target in colorectal cancer. Oncotarget 7: 14765-14780, 2016.

20. Jiang L, Jiang S, Lin Y, Yang H, Zhao Z, Xie Z, Lin Y and Long $\mathrm{H}$ : Combination of body mass index and oxidized low density lipoprotein receptor 1 in prognosis prediction of patients with squamous non-small cell lung cancer. Oncotarget 6: 22072-80, 2015.

21. Li X, Tang H, Wang J, Xie X, Liu P, Kong Y, Ye F, Shuang Z, $\mathrm{Xie} Z \mathrm{Z}$ and $\mathrm{X}$ ie $\mathrm{X}$ : The effect of preoperative serum triglycerides and high-density lipoprotein-cholesterol levels on the prognosis of breast cancer. Breast 32: 1-6, 2017.

22. Chen W, Zheng R, Zhang S, Zeng H, Fan Y, Qiao Y and Zhou Q: Esophageal cancer incidence and mortality in China, 2010 Thorac Cancer 5: 343-348, 2014

23. Singh S, Sharma AN, Murad MH, Buttar NS, El-Serag HB Katzka DA and Iyer PG: Central adiposity is associated with increased risk of esophageal inflammation, metaplasia, and adenocarcinoma: A systematic review and meta-analysis. Clin Gastroenterol Hepatol 11: 1399-1412.e7, 2013.
24. Corrao G, Bagnardi V, Zambon A and La Vecchia C: A meta-analysis of alcohol consumption and the risk of 15 diseases. Prev Med 38: 613-619, 2004.

25. Chen P, Han L, Wang C, Jia Y, Song Q, Wang J, Guan S, Tan B, Liu B, Jia W, et al: Preoperative serum lipids as prognostic predictors in esophageal squamous cell carcinoma patients with esophagectomy. Oncotarget 8: 41605-41619, 2017.

26. Zhou T, Zhan J, Fang W, Zhao Y, Yang Y, Hou X, Zhang Z, He X, Zhang Y, Huang Y and Zhang L: Serum low-density lipoprotein and low-density lipoprotein expression level at diagnosis are favorable prognostic factors in patients with small-cell lung cancer (SCLC). BMC Cancer 17: 269, 2017.

27. Rodrigues Dos Santos C, Fonseca I, Dias S and Mendes de Almeida JC: Plasma level of LDL-cholesterol at diagnosis is a predictor factor of breast tumor progression. BMC Cancer 14: 132, 2014.

28. Wettstein MS, Saba K, Umbehr MH, Murtola TJ, Fankhauser CD, Adank JP, Hofmann M, Sulser T, Hermanns T, Moch H, et al: Prognostic role of preoperative serum lipid levels in patients undergoing radical prostatectomy for clinically localized prostate cancer. Prostate 77: 549-556, 2017.

29. Liu YL, Qian HX, Qin L, Zhou XJ and Zhang B: Serum LDL-C and LDL-C/HDL-C ratio are positively correlated to lymph node stages in males with colorectal cancer. Hepatogastroenterology 58 : 383-387, 2011.

30. Sako A, Kitayama J, Kaisaki S and Nagawa H: Hyperlipidemia is a risk factor for lymphatic metastasis in superficial esophageal carcinoma. Cancer Lett 208: 43-49, 2004.

31. Mehta N, Hordines J, Sykes D, Doerr RJ and Cohen SA: Low density lipoproteins and Lovastatin modulate the organ-specific transendothelial migration of primary and metastatic human colon adenocarcinoma cell lines in vitro. Clin Exp Metastasis 16: 587-594, 1998.

32. Li Y, Wood N, Grimsley P, Yellowlees D and Donnelly PK: In vitro invasiveness of human breast cancer cells is promoted by low density lipoprotein receptor-related protein. Invasion Metastasis 18: 240-251, 1998.

33. Montel V, Gaultier A, Lester RD, Campana WM and Gonias SL: The low-density lipoprotein receptor-related protein regulates cancer cell survival and metastasis development. Cancer Res 67: 9817-9824, 2007.

34. Li C, Zhang J, Wu H, Li L, Yang C, Song S, Peng P, Shao M, Zhang M, Zhao J, et al: Lectin-like oxidized low-density lipoprotein receptor-1 facilitates metastasis of gastric cancer through driving epithelial-mesenchymal transition and PI3K/Akt/GSK3 $\beta$ activation. Sci Rep 7: 45275, 2017.

35. Langlois B, Perrot G, Schneider C, Henriet P, Emonard H, Martiny L and Dedieu S: LRP-1 promotes cancer cell invasion by supporting ERK and inhibiting JNK signaling pathways. PLoS One 5: e11584, 2010

36. Gopal U, Bohonowych JE, Lema-Tome C, Liu A, Garrett-Mayer E, Wang B and Isaacs JS: A novel extracellular Hsp90 mediated co-receptor function for LRP1 regulates EphA2 dependent glioblastoma cell invasion. PLoS One 6: e17649, 2011.

37. Lu CW, Lo YH, Chen CH, Lin CY, Tsai CH, Chen PJ, Yang YF, Wang CH, Tan CH, Hou MF, et al: VLDL and LDL, but not HDL, promote breast cancer cell proliferation, metastasis and angiogenesis. Cancer Lett 388: 130-138, 2017.

38. Holland JA, Pritchard KA, Rogers NJ and Stemerman MB: Perturbation of cultured human endothelial cells by atherogenic levels of low density lipoprotein. Am J Pathol 132: 474-478, 1988.

39. RedlH,Schlag G,KneidingerR, OhlingerW andDavies J: Response of the endothelium to trauma and sepsis. Adherence, cytokine effects and procoagulatory response. Arzneimittelforschung 44: 443-446, 1994.

40. Staudt ND, Jo M, Hu J, Bristow JM, Pizzo DP, Gaultier A, VandenBerg SR and Gonias SL: Myeloid cell receptor LRP1/CD91 regulates monocyte recruitment and angiogenesis in tumors. Cancer Res 73: 3902-3912, 2013.

41. McCarthy BM, Okano Y, Nakayasu T, Macy M, Watson SR and Harmony JA: Plasma lipoproteins and transferrin regulate the proliferation of a continuous T lymphocyte cell line. J Lipid Res 28: 1067-1077, 1987.

42. Stewart-Phillips JL,Lough J and Phillips NC: Theeffect of a high-fat diet on murine macrophage activity. Int J Immunopharmacol 13 325-332, 1991.

This work is licensed under a Creative Common Attribution-NonCommercial-NoDerivatives 4.0 International (CC BY-NC-ND 4.0) License. 